Journal of Arts

Cilt / Volume 2, Sayı / Issue 2, 2019, pp. 113-128

E - ISSN: 2636-7718

URL: http://ratingacademy.com.tr/ojs/index.php/arts/index

DOİ: https://doi.org/10.31566/arts.2.008

Araştırma Makalesi / Research Article

\title{
ÇAĞDAŞ GÖSTERİ SANATLARINDA BİR ANLATIM ARACI OLARAK KUKLA*
}

\author{
PUPPET AS A FORM OF EXPRESSION IN CONTEMPORARY \\ PERFORMING ARTS
}

\author{
Işınsu ERSAN * \\ * Arş.Gör.Dr., Dokuz Eylül Üniversitesi, Güzel Sanatlar Fakültesi, Sahne Sanatları Bölümü, Sahne \\ Tasarımı Anasanat Dal, İzmir/TÜRKIYE, E-mail: isinsuersan@gmail.com \\ ORCID ID: https://orcid.org/0000-0002-0946-7163
}

Geliş Tarihi: 1 Mart 2019; Kabul Tarihi: 26 Nisan 2019

Received: 1 March 2019; Accepted: 26 April 2019

\section{$\ddot{O Z Z E T}$}

Kukla tiyatrosu, konvansiyonel olarak oyun kişilerinin kuklalar tarafindan canlandirlldı̆̆g, dolayısıyla oyuncunun yerini kuklanın aldı̆̆g bir gösterim türdür. Kuklanın sahnede tek ve belli bir rolü oynadığı konvansiyonel sahneleme biçimi bugün hala devam etmekle birlikte; 20. yüzyll sahneleme örnekleri açısından değişimi beraberinde getirmiştir. Avant-garde hareketlerle birlikte tüm sanat disiplinlerinde gerçekleşen değişimin yanı sıra teknolojik gelişmeler ve iletişim biçimlerinin evrimi de buna zemin oluşturmuştur. Dolayısıyla hem kumpanyalar farklı deneysel uygulamalar yapmıs hem de farklı sahne sanatlarının öncülüğ̈̈nde disiplinlerarası çalışmalar gerçekleşmiştir. Bu çalışma, kuklanın bir anlatım aracı olarak özellikle çağdaş gösteri sanatlarındaki yerini ortaya koymaktadır.

Anahtar Kelimeler: Kukla, anlatım, çağdaş, tiyatro

\section{ABSTRACT}

Puppet theater is a kind of presentation in which conventionally puppets represent fictional characters therefore they replace actors on stage. Even though a conventional staging encapsulates puppets standing for a specific character is continuing; 20th century provided a transformation in staging. The alteration of all art disciplines together with Avant-garde movements, technological advancements and evolution of communication provide a base for this transformation. Hence both companies experienced a variety of experimental practice and interdisciplinary practices occurred that led by different performing arts. This paper, reveal puppetry's place in contemporary performing arts as a form of expression.

Keywords: Puppet, expression, contemporary, theater 


\section{GİRIŞ}

Konvansiyonel kukla oyunları, tüm dünyada, geçmişten günümüze hala oynanmakta ve izlenmektedir. Onlar bir açıdan korunması ve sürdürülmesi gereken bir geleneğin parçasıdırlar. Konvansiyonel kukla oyunlarında kuklanın canlı olduğu illüzyonu yaratılmak istenir ve bu sebeple onu harekete geçiren kuklacı sahne arkasında kalarak gizlenmektedir. El kuklası kabininin yüksekliği bu sebeple oynatıcının boyuna göre ayarlanmaktadır. Gölge tiyatrosunun hem Çin hem Avrupa örneklerinde oynatıcı elinin gölgesi perdede görülmez. İpli kukla sahnesinin çerçevesi de kuklaların boyuna göre ayarlanmalıdır. Özellikle Avrupa kukla gelenekleri için kuklacının kendini gizlemesi bir kural gibi uygulansa (McCormick ve Pratasic, 2004: 87-90) da Asya geleneğinde Nang Sbek Thom (Kamboçya), Wayang Kulit (Endonezya) ve Bunraku (Japonya) gibi kukla oyunu türlerinde kuklacı, kukla ile birlikte sahnede görülmektedir. Kamboçya'daki üç gölge oyunu tekniğinden biri olan Nang Sbek Thom örneğinde; oynatıcılar gölge figürlerinin yanında görünürdür, onlarla dans ederler ve mim, şarkı, dans ve anlatının birlikte kullanımı oyunu oluşturmaktadır. Konularını daha çok destan ve dini hikayelerden alan bu oyunların kahramanlarını canlandıran kuklaların bir ruh taşıdığına inanılmaktadır. Kimi dini törenler içinde gerçekleşen bu gösterilerdeki kuklalar hem kuklacı hem de izleyiciler tarafindan belli bir oranda kutsal sayılmaktadırlar. İlahi olanı temsil eden kuklalar, bu sebeple yine canlı olarak görülmekte, kuklacının görünür olması bu algıyı değiştirmemektedir.

Çağdaş gösterimlerin geleneksel türleri dışarıda bırakarak salt yeniyi ortaya koymak gibi bir hedefi yoktur; esasen geleneksel olandan beslenmektedirler. İpli kukla, gölge kuklası, el kuklası ve Japon bunraku gibi geleneksel teknikler, çağdaş sahnelemelerde de kullanılırlar. Gelenekselden farklı olarak bu türlerden bazen birkaçı aynı oyunda bir araya gelirler. Kullanılan tekniğin ötesinde çağdaş kukla oyunları multi-disipliner ve çoğunlukla kültürler ötesi bir yapıdadır. Avangard akımlarla başlayan değişim rüzgarının bir sonucu olarak, farklı sanat disiplinlerinden gelen sanatçılar birlikte üretmek konusunda çok daha isteklidirler. Dolayısıyla sahne sanatları açısından disiplinlerarası çalışmalar, 20. yüzyılın başından beri yenilikçi sonuçlar doğurmuş ve doğurmaktadır. Kukla tiyatrosu bu bağlamda, özellikle 2000'li yıllarda konvansiyonel kimliğinin ötesinde sanatsal üretime katkı sağlayan bir konumdadır. Bugün farklı disiplinler arasındaki sınırlar çözülmekte; gelişen teknolojiyle, hızlı iletişim ve kolaylaşan ulaşım, kültür sınırlarının da keskinliğini azaltmakta; uluslararası festivaller aracılığıyla kukla sanatçılarının içinden doğdukları kültürden çok daha başkalarına ulaşmalarına olanak tanımaktadır. Çağın getirisi olan görsel kültür, iletişim açısından etken belirleyen haline geldikçe görsel imgelerin önemi artmaktadır. Bu da kuklayı, tüm sahne sanatları için son derece işlevsel bir anlatım aracı haline getirmektedir. Elbette bu, kuklanın kendi türünün baş aktörü olmaktan çıkıp araçsallaşarak değersizleşmesi anlamına gelmemektedir. Kukla seyirci ile iletişim kurabilen etkili ve dinamik bir araçtır. Zira disiplinlerarası çalışmalar içinde yer aldığında anlam oluşturma ve anlatımı zenginleştirme açısından eşsizdir.

\section{2.ÍLETIŞIMM ARACI OLARAK KUKLA}

İletişim; aktaran ya da alımlayan tarafından erişilebilir olan ve özünde kendinden başka bir şeyi ifade eden simge ve kodlar vasıtasıyla oluşan mesaj yoluyla sağlanan sosyal etkileşimdir (Fiske, 1996: 1-2). Bilgi, düşünce, duygu, deneyim ve birikimleri içeren mesajlar, sözlü, yazılı ya da görsel olarak aktarılabilir. Roman Jakobson'un dilsel iletişim şemasına göre iletişim, verici ile alıcı arasında bildiri (bağlam [gönderge], kanal, kod) aracılığıyla gerçekleşmektedir (Günay, 2012: 11). İçeriğin yaygın biçimde anlaş1lması için ise bugün görsel araçlar daha yaygın biçimde tercih edilmektedir. Zira görsel malzemeler, hızlı bir iletişimi de olanaklı kılmaktadır. Görsel sembol, imge ve nesneler, kaynağı, kullanım değeri, değişim değeri ya da üretilme biçimi sebebiyle bir anlam çağrışımına sebep olmaktadır. Albert 
Mehrabian (1971: 43) kişilerarası iletişimde ilk izlenimde etkinin nasıl olduğu konusunda yaptığ 1 araştırmada görüntünün $\% 55$, ses tonunun $\% 38$, sözün ise $\% 7$ oranında etkili olduğunu ortaya koymuştur. Mehrabian'ın bulguları kişinin görüntüsünün ve hareketlerinin diğerleriyle iletişimde, sözlerinden daha fazla etkili olduğu yönündedir.

"İmgeler bir fikri iletmenin en güçlü araçlarıdır. Modern baskı süreçlerindeki gelişmeler, dijital fotoğrafın popülerliğindeki artış, imge kütüphanelerinin ulaşılabilirliği ve çeşitliliği, fotografik imgelerin daha önce hiç olmadığ kadar ucuz ve ulaşılabilir olmasına katkıda bulunmuştur" (Ambrose ve Harris, 2013: 99).

Düşünce ve duyguların iletimi, görsel çağrıştırma yolu ile yapıldığında alımlayıcının öznel yorumuna da açık olacağından sözlü ve yazılı bir açıklamadan çok daha etkilidir. Zira alımlayıcıya/seyirciye direkt anlatım mesajı çözümlemekten alacağı estetik hazzı azaltacaktır. Göstergebilim teorisyenlerinden Roland Barthes (2002) da metin okumalarının kodlar vasıtasıyla yapıldığında, alımlayıcının anlatıyı farklı anlam çerçevelerinde okuyabildiğini ortaya koymuştur. Bilinçdışı olarak gerçekleşen kod çözümleme süreci, verilerin direkt çağrışımları ve taşıdıkları mesaj ya da anlam kadar, yan anlamları ve alımlayıcının öznel geçmiş yaşanmışlıkları bağlamında gerçekleşmektedir. Bu durumda görsel veriler ile sağlanan dolaylı çağrışım ya da anıştırma alımlayıcı için daha etkili bir hale gelmektedir.

Metin, gösteri sanatlarında anlatımın temel öğelerinden biri olarak son derece önemlidir. Ancak görsel verilerin yargı oluşturmada kayda değer öneme sahip olması dolayısıyla sahnede kuklanın, ilk görüldüğü andan, oyunun sonuna dek dış görüntüsü, varsa kuklacı ile olan etkileşimi, sahne üzerindeki konumu ve hareketi, anlatılmak istenenin iletilmesi için yeterlidir. Çağdaş oyunlarda metin bu anlamda giderek, daha çok sahne direktiflerini içeren bir sahne metnine dönüşmektedir.

İfade biçiminin görsel olması, izleyicide uyandıracağı etkiyi arttırmasının yanı sıra onun anımsanmasını da kolaylaştırmaktadır. Görsel dili optik iletişim olarak da tanımlayan Kepes, 20. yüzyıl ortalarında görsel iletişimin değerini vurgulamıştır. Görsel dil, bilgiyi, neredeyse diğer tüm iletişim araçlarından daha etkili biçimde yayma kapasitesine sahiptir. İnsan, görsel dil vasıtasıyla deneyimlerini nesne formunda ifade edip aktarabilir. Görsel iletişim, dil ya da gramer engeli tanımadığı ve okuryazarlar kadar okuma yazma bilmeyenlerce de algılanabildiği için evrensel ve uluslararasıdır. Görsel dil, fikir ve gerçekleri diğer iletişim yöntemlerinden daha geniş ve derin bir aralıkta sunabilmekte; hatta durağan olan sözlü bir konsepti, dinamik görselin duyusal canlılığı ile destekleyebilmektedir (Kepes: 1969, 13). Televizyon, bilgisayar, internet ve akıllı telefonlar, bugün ekran odaklı bir hayata sebep olmaktadır. Görsel verilerin güçlü etkisi ve bu araçların yaygınlaşması birbiriyle doğru orantılıdır. Neredeyse günlük hayatı, çevrede olan biteni anlama ve anlamlandırma biçimini etkileyen, onu yeniden şekillendiren bir yapı söz konusudur. Bu durum, insanlar arası iletişim biçimini de doğrudan etkilemektedir.

"Her tür iletişimin göstergeler ve kodlar içerdiğini düşünüyorum. Göstergeler, kendilerinden başka bir şeye gönderme yapan eylemler ya da yapılardır, yani anlamlandırma yapılarıdırlar. Kodlar, içinde göstergelerin düzenlendiği ve göstergelerin birbirleri ile nasıl ilişkilendirilebileceğini belirleyen sistemlerdir. [...] Göstergeleri/kodlari/iletişimi aktarma ya da alma, bir toplumsal ilişkiler pratiğidir" (Fiske, 1996: 16).

Fiske'in gösterge ve kodlarla dolu olduğunu ifade ettiği iletişim, görsel imgelere dayanan bir iletişimi daha fazla etkin kılan akıllı telefonlar ile tam karşılığını bulmaktadır. Görsel sanatlar ve teknoloji ürünü araçlarla tekrarlı karşılaşmaların ürünü olarak, günlük deneyimleri ve gelecekte karşılaşılacak durumları değerlendirip yapılandırmak için, bir dil ya da gramer ortaya çıkmaktadır. Görsel gramer canlı ve esnek anlatım olanakları sağlamanın yanında; anlar arasında bă̆ kurmakta ve onları basitleştirmektedir (Hayler, 2016: 164-165). 
Kukla tiyatrosu, izleyicisine anlatmak istediğini iletmek için tam olarak bu görsel grameri kullanmaktadır. Oyunlar sözlü ya da sözsüz olsun, kuklanın kendisi görsel bir ifade biçimidir.

İletişim araçlarının, sunumsal, temsili ya da mekanik olabildiğini belirten Fiske'e göre sunumsal araçlar, ses, yüz, beden, sözcükleri ve ifadeleri kullanan iletişim kuran kişinin kendisi de olabilir (1996: 36). Sunumsal iletişim araçları, oyuncu tiyatrosunda olduğu kadar kukla tiyatrosunda da kullanılmaktadır. Yüz ifadesi, beden dili, müzik, efekt, ses tonu gibi görsel ve işitsel anlatımla birlikte dokunma duyusu da kaynaktan alıcıya gönderilmek istenen mesajın duygu, düşünce ve davranışlarla kodlanmasını sağlamaktadır. Sahnede, sözlü mesajı destekleyen ya da onun yerine geçen görsel dil, hareket dilini de kapsar. Oyuncu için olduğu gibi kukla için de ses, yüz, beden ve sözcükler birer ileti aracıdır, hatta kukla ve oyuncunun kendisi temsil ettiği şeylerle başlı başına bir iletişim aracıdır. Sahnedeki oyuncu/kukla ve seyircinin yüz yüze olması ve oyunun canlı icra edilmesi, seyirci tepkisinin anında alınabilmesine olanak vermektedir. Bu durum, sahne ve salon arasında, sözlü ya da sözsüz olsun bir mesaj iletimini olanaklı kılmaktadır. "Antik çağlardan beri kuklalar sembol ve metafor kaynakları olmuşlardır. Bu sanat geliştikçe kuklalar kendi içinde bir amacı olan şeyler değil birer araç olarak görülmeye başlamışlardır" (Meschke, 1992). Kukla tiyatrosu geliştikçe teorisyenler kuklanın ne olduğu ve işlevi üzerine de fikir geliştirmeye başlamışlardır.

Kukla tiyatrosunda, çatışma ve duygular, sahne üzerinde kukla denen ve hareket eden görsel formlar ve kelimelerden yaratılmaktadır. Figürün kullanım biçimi, onun kukla olup olmadığını belirler. (Wanrooy, 1995: 8) Amerikalı kukla kuramcısı Paul McPharlin kuklayı insan kontrolü altında hareket eden tiyatral bir figür olarak tanımlamıştır (1969: 1). Amerikan kuklacılığının önde gelen isimlerinden Bill Baird de kuklayı insan kuvveti ile seyirci önünde hareket ettirilen cansız bir figür olarak nitelemiştir. Yine kukla üzerine kuramsal çalışmaları bulunan Steve Tillis, bu tanımlara Polonyalı kukla kuramcısı Henryk Jurkowski'nin konuşan ve gösteri yapan nesne (2000: 11) göndermesini de ekleyerek kendi tanımını oluşturur. Ona göre,

"İnsanlar kuklalar hakkında konuşurlarken, seyirci tarafından algılanan figürlerden bahsederler öyle ki tasarım, hareket ve çoğunlukla konuşma eklenmiş nesneler olarak seyirci onların canlı olduğunu hayal eder" (Tillis, 1992, s. 28).

Kuklayı teknik olarak tanımlayan yukarıdaki teorisyenlerin aksine, Rus kukla ekolünün önemli isimlerinden Sergei Obraztsov kuklanın özünü hedef almıştır. Ona göre kukla, yaşayan bir şeyin taklidinden öte bir alegoriye dönüştürülmüş kolektif bir imgedir (Obraztsov, 1985: 181). Yani kukla, çoğunlukla tasarım ürünü olan, el yapımı, seyirci önünde canlı olduğu yanılgısını oluşturacak biçimde temsil ettiği karakter, tip, duygu, ya da düşüncenin özelliklerine uygun biçimde, dışarıdan bir kuvvet uygulanarak hareket ettirilen bir gösteri nesnesidir. Adını verdiği tiyatro biçiminin baş aktörüdür. "Kukla sembolik karakteri sebebiyle en zengin olanakları sunmaktadır. Bazen belli bir ifade biçimi tedirgin edici olabilir çünkü kuklalar güçlü uyarıcılardır" (Wanrooy, 1996a: 5). Kuklayı harekete geçiren ve onu sahnede canlı hale getiren oynatıcı ya da kuklacı, anlam üretiminde kukla kadar önemlidir.

Kuklanın aynı anda nesne ve özne olabilme durumu ile bu durumda oynatıcısı ile değişen ilişkisi; yalnızca onun sahne üzerindeki gücünü arttırmaz, aynı zamanda seyircinin de daimi olarak sahnede olan biteni ve değişen ilişkiyi düşünmesine yol açar. Kukla tiyatrosunun, geleneksel tüm türleri devam etse de bugün konvansiyonel kukla tiyatrosunun sinırlarının ötesinde, kültür sınırlarını da zorlayan disiplinlerarası çalışmalarla ortaya konan sahnelemeler söz konusudur. Avangard akımların başlattığı işbirliği ve sanatta özgürleşme, dönemin sahne sanatları ve kukla tiyatrosu üzerinde de etkili olmuştur. Disiplinlerarası çalışmaların neredeyse tanımlayıcı özelliği haline gelen çağdaş kukla tiyatrosunda bu bağlamda yeni bir avangard dönem yaşanmaktadır. Sahne sanatlarının diğer türleri giderek kuklanın sembolik ifade gücünü 
ve işlevlerini daha fazla kabul edip yapımlarının birer parçası kılmakta bu yolla da kuklanın yeri görünür biçimde meşrulaşmaktadır.

Kukla duayeni, tarihçi ve teorisyen Henryk Jurkowski, 1992 tarihli Aspects of Puppetry başlıklı konuşmasında, "kukla kişisel ya da politik ifade için kullanılsa da yapay bir sanat değil disiplinlerarası bir sanattır; bu sebeple kuramcılar kukla araştırmalarında disiplinlerarası metotları uygulamalıdırlar. Bugün konu ve edebi metotlar arasında bir karşıtlık vardır- her yerde kolaj kullanılıyor" (Akt. Wanrooy, 1996a: 15) demiştir. 20. yüzyılda başlayan bu disiplinlerarasılık, sonraki yüzyılın kukla tiyatrosunun ana karakterini oluşturmaktadır. Pek çok kumpanya disiplinlerarası işbirliklerine önem vermekte ve çalışmalarında başka disiplinlerden sanatçılara daha çok yer vermektedirler. Öyle ki La Compagnie l'Alinéa gibi kimi kumpanyalar bu işbirliklerini kendilerini tanımlayan öğelerden biri olarak görmektedir.

"La Compagnie l'Alinéa deneyimleri ve kukla çevresinden olsun olmasın farklı sanatçıları, yönetmenleri, müzisyenleri, görsel sanatçıları vb. bir araya getiren bir erime noktasıdır. $\mathrm{Bu}$ insani ve sanatsal karşılaşmalar, bilgilerimizin bir araya geldiği, tutku ve yeteneklerimizin buluştuğu noktada bizi başarılara yöneltir. Bugün dileğimiz, söze daha az dayanan, müzik ve el kuklası ile daha tutkulu projeler çerçevesinde paylaşım ve ortaklıklara her zamankinden fazla olanak sağlamak, sürdürmektir- Brice Coupey". (La Compagnie l'Alinéa, 2017)

Disiplinlerarası çalışmalarda, kukla direkt olarak görsel sembol işlevi üstlenmektedir. Bir düşünce, bir duygu, bir felsefe ya da bir ideolojinin somut yansıması olarak sahneye gelebilmekte; sözle iletimin ötesinde bir etkiyle estetik olarak seyirciye tesir edebilmektedir. Konvansiyonel olarak başlangıcından beri görsel bir dil kullanan kukla tiyatrosunun çağdaş formlarında, görsel anlatım, daha simgesel bir boyut kazanarak anlam oluşturmanın temeli haline gelmektedir. Özellikle uluslararası seyirciye hitap eden oyunlar için anlaşılır olmak son derece gerekli hatta yapımın temeli olduğundan; çoğu oyun sözsüz ve genele hitap edecek biçimde tasarlanmaya çalışılır. Bu bağlamda sahneye koyanlar, anlaşılırlığı arttırmak için çoğunluk tarafindan tanınan ve yaygın olan imge ve kodlardan faydalanmaktadırlar. "Simgeler, resimsel olarak gösterilmesine rağmen çoğunlukla, temsil ettikleri kavramları, düşünceleri ya da nesneleri anlatmak için kullanılır. Ortak simgelerin tanınabilme kolaylığı onları güçlü bir tasarım aracı kılar" (Ambrose ve Harris, 2013: 144). Çağdaş kukla tiyatrosu kadar disiplinlerarası sahnelemeler de kuklaları anlamı oluşturacak, geliştirecek ve güçlendirecek birer araç olarak kullanmaktadır. Dolayısıyla kukla konvansiyonel olarak amaç iken, çağdaş örneklerde hem amaç hem de araç bazen de sadece araç olmaktadır.

Kuklayı imgeleştiren, izleyici tarafından tanınmasını ve algılanmasını sağlayan unsurlar söz konusudur. Bu unsurlar, tasarım, hareket ve içeriğin uyumlu bütünlügüüdür. Tema kapsamı ve sınırları belirler, tasarım bunu görselleştirir ve hareket ise kuklayı canlandırır ve anlamı kelimenin tam anlamıla boyutlandırır. Sahne üzerindeki hareketle birlikte kukla ve kuklacı arasındaki etkileşim de farklı imgelerin oluşmasına ve anlatımın zenginleşmesine katkıda bulunmaktadır. Görsel imgeyi oluşturan şey, temelde onun tasarımı olarak algılanır; ancak tasarım hem görsel hem de fikirsel olanı kapsar. Özellikle sahne metni üzerinden giden çalışmalarda, sanatçılar temayı, fikri, konuyu veya mesajı en iyi aktaran aracı aradıklarından, deneme yanılma yolu ile çalışırlar ve bu bağlamda değişiklik yapma konusunda esnek bir bakış açısına sahiptirler. Temsil edilecek fikir/tema/konu/anlam tasarımı önceleyebilir ve reji masasında kararlaştırılabilir ama nesnenin kendisinden yola çıkarak temsiliyeti belirlemek ve anlam karşılığını prova odasında deneyimlemek de mümkündür. Hareket de bu noktada anlamı bütünlemektedir. Dolayısıyla özelikle çağdaş kukla çalışmaları için fikir ile görsel tasarımın hareketle birlikte sürekli dirsek temasında olduğunu söylemek daha doğru olacaktır. $\mathrm{Bu}$ unsurları sahneleme açısından birbirinden ayrı düşünmek mümkün olmasa da daha iyi anlamak için kendi içlerinde değerlendirmek gereklidir. 


\subsection{Tasarım}

Görsel iletişimin giderek daha etkin olduğu 21. yüzyılda tasarım, gösteri sanatları için işlevsel bir öneme sahiptir. Oyuna uygunluk, estetik bütünlük sağlamanın yanı sıra seyirciyi şaşırtmak, büyülemek ve ilgisini sürekli canlı tutmak için tasarıma ihtiyaç vardır. Tasarımı meydana getiren unsurlar yani malzeme, renk, biçim ve biçimi oluşturan çizgiler; kuklanın görünüşünü oluşturmanın yanı sıra kendi özünde taşıdığı anlamla da kuklanın oyundaki anlamsal işlevine katkıda bulunmaktadır. Taş, kâğıt ya da kumaş ve benzeri malzemeler insanların onlarla kurmuş olduğu dokunma duyusu temelli ilişki ve onları kullanım biçimleri hatta değişim değerleri sebebiyle, kuklanın temel malzemesi olarak kullanıldıklarında, anlam ve çağrışım çerçevesine doğrudan katkıda bulunmaktadırlar. Kukla, salt malzeme olarak, tasarım ürünü el yapımı hatta hazır ürün olarak sahnede çağrışım alanını genişletmektedir. Kukla toplulukları malzemelerini oyunun içeriğine göre sembolik bir bağ kurmak için bilinçli olarak seçebilmektedir. Kukla bu şekilde, anlam iletme amacıyla kullanıldığında imgeye dönüşerek çağdaş oyunlara hizmet etmektedir. Bu anlamda sözün yerini alabilecek simgesel tercihler giderek yaygınlaşmaktadır. Tasarlanmış kuklalar kadar hazır nesneler de simge ve kodların somut biçimi olabilmektedir.

Direkt nesnelerin kukla gibi canlandırıldığı obje tiyatrosunda objenin günlük işlevinden gelen birincil anlamının yanı sıra oyun dramaturgisine uygun olarak yüklenmiş rol de işlevsel bir anlam ifade eder. Nitekim "nesneler sadece ilham kaynağı olarak görüldükleri zaman hak ettikleri kadar takdir edilmemektedirler. [Oysa] Onlar genellikle bir performansa biçim ve içerik veren araçlardır" (Vogels, 1998: 31).

Hazır nesneler, kendi kullanım değerleri ve tasarımları çerçevesinde temel ve yan anlamlar taşımaktadırlar. Bu temsil kabiliyeti onları, kimi oyun kişilerinin yerine kullanmak için son derece elverişli kılmaktadır. Dolayısıyla malzemenin kendisinin oyun kişisi olması gibi, nesneler de öykü anlatımının bir parçası olarak oyunda doğrudan rol almaktadırlar. Kukla tiyatrosu, nasıl ana oyun kişisi kukla olduğu için bu adı alıyorsa; her ne kadar prensipleri kukla tiyatrosuyla aynı olsa da oyun kişisi nesne olan tiyatro da Obje tiyatrosu (Object Theater) olarak anılmaktadır. Konvansiyonel kukla tiyatrosunda rastlanmayan hazır nesne kullanımı, Avangard sanatla birlikte yıkılan ana akım kuralların yarattığı sanatta özgürleşmenin sonucudur denilebilir. Marcel Duchamp'ın öncülügünü yaptı̆̆ı ready-made (hazır nesne) yapıtlar, döneminin ana akım sanat anlayışına nasıl karşı duruyorsa; sıradan nesnelerin kukla sahnesinde birer karaktere dönüşmesi de geleneksel anlayışta kuklacının el emeği olan kuklalarla tam bir karşıtlık içindedir. Ancak sahne üzerinde hazır nesnelerin kullanılması, ready-made'ler gibi keskin bir başkaldırı içermemektedir. Yine de kukla yapımını, zanaat ve sanat olma halinden uzaklaştırmaktadır. Avangardın, sanat eserinin üstünlüğü yerine sanatçı ve sanatçının düşüncesini koyması gibi kukla tiyatrosunda da fikrin ve temsilin önemini vurgulamaktadır. Çağdaş oyunlar oyun kişisi olarak, kukla ve oyuncu yanında nesnelere de yer verebilmektedir. Nitekim sahne üzerinde ne varsa, imge yoluyla iletilmek istenen mesajı ve anlatılmak istenen öyküyü netleştirmek için birer araç olmaktadır.

"Nesneleri kukla gibi kullanmak hareket, devinim ve diğer aksiyonlara daha fazla esneklik sağlar, kuklalar oyuncuların yapamadığı şeyleri yapabilir" (Wanrooy, 1996: 5). Sadece görsel tasarımlarıyla ya da basitçe dış görünüşleri ile temsil ettikleri şeyler arasındaki doğrudan ya da dolaylı bağ bile anlamı derinleştirir ve kukla/nesnenin bir oyuncunun temsil ettiğinden fazlasını temsil etmesini sağlar. Dolayısıyla kukla/nesne sahnede, hareket etmese bile salt varlığıyla oyuncunun yapabildiğinden fazlasını yapmaktadır. Çağdaş kukla tiyatrosunun özünü oluşturan da kuklanın oyuncudan hareket ve anlam katmanı bakımından daha fazlasını sunabilmesidir. Bu bağlamda oyun mekânı da sahneye koyanların elinde nesneleşerek; anlam üretecek ve anlatımı gerçekleştirecek biçimde araçsallaşmaktadır. Bunun sonucu olarak alımlayıcının algı perspektifi ile oynayan kumpanyalar için mekan ya da uzamın kendisi de ileti 
oluşturma konusunda kinetik bir araca dönüşmektedir. Mekan, bir tiyatro sahnesi ya da ipli kukla sahnesi, el kuklaları için kabin ve gölge perdesi gibi konvansiyonel biçimlerin dişında bir yer olarak seçildiğinde ya konvansiyonel kullanım kurallarının dışına çıkıldığında kuklalar için bir zemin ya da fon olmanın ötesinde anlam oluşturan işleve kavuşmaktadır. Yeri geldiğinde kendi değişmez ve sağlam yapısından beklenmeyecek şekilde hareket etmektedir.

Kuklalar bilinçli olarak, belirgin karakteristik özellikler taşımayacak biçimde tasarlanabilirler, bu durumda belirgin bir kişilik özelliği, yaş ya da cinsiyet belirtmeyecek biçime sahip olurlar. Böyle bir tasarım tercihi kuklaların temsil becerisini azaltmaz aksine çoklu temsillere olanak tanır. Kukla böyle nötr bir tasarımla bir değil pek çok kişiliği ifade edebilir; ya da sıradan herhangi biri olabilir. Diğer gösteri sanatlarında kukla, böyle nötr bir görünümde tercih edilebileceği gibi, anlam iletimi açısından yaygın imgelerin temsili olarak da son derece işlevseldir. Kuklanın kendisi mesaj üretiminde başlı başına bir imge olarak hizmet etmektedir. İmgenin oluşturulmasında ise şeyleri meydana getiren unsurların tamamı değil, özü yeterli olmaktadir.

Öz, fiziksel objelerle ilgili günlük ortak algıyı meydana getiren şeylerden biri olup; bilinçdışı kavramsal sistemlerin bir parçasıdır ve her gün kullanılan mantığı yönetmektedir. Ağaç örnek olarak alınırsa, anlık bir şekilde herhangi bir ağaç düşünülür. Bir ağacı ağaç yapan, yani onun özünü belirleyen, malzeme (ahşap), form (gövde, dallar, kökler, yapraklar) ve değişim şemasıdır (tohumdan büyür ve çürür). Her şeyin de bir özü vardır. Bir fill için bunlar kulakları, hortumu, kolon gibi bacaklarıdır ve bu bağlamda öz, doğal davranış kalıplarını da belirlemektedir. Dolayısıyla filler ayakları yiyecekleri kavramaya uygun yapıda olmadığ 1 için hortumlarıyla yemek yemektedirler (Lakoff ve Nunez, 2000: 108). Lakoff ve Nunez'in öz olarak ifade ettiği şey doğrudan imgeyi oluşturan şeydir ve bir kukla karakterini oluştururken kuklacının da bu öze dikkat etmesi gerekmektedir.

\subsection{Hareket}

Tasarım, anlamı oluşturma ve ifade anlamında çok güçlü bir veri sağlayıcı olsa da kukla tiyatrosu gibi bir formda hareket ve hareketin biçimi de kesinlikle mesaj iletmede etkin bir rol oynamaktadır. Bu noktada, hareketin dinamiği kadar, beden dili çözümlemeleri de icracı için iletilmek istenen niyeti ortaya koyma konusunda, izleyici için de niyeti okuma anlamında son derece işlevsel olmaktadır.

Kuklanın anatomisi ne olursa olsun, kuklanın herhangi bir insanın gerçek hayatta yapamayacağı bir eylemi gerçekleştirmesi onun dramatik anlatıma katkıda bulunmasını sağlamaktadır. Uçma eylemi ya da ayakların yerden kesilmesi bu eylemlerden biridir ve sahnede çeşitli çağrışımları meydana getirmektedir. Rüya gördüğü için, mutluluktan, öldüğü için, yüceleştiği ya da statüsü yükseldiği için kuklanın varsa ayaklarının yerden kesilmesi, göğe yükselmesi ya da uçması vasıtasıyla somutlaştırılabilmektedir. Böylelikle dildeki mutluluktan uçmak gibi mecazlar bil fiil sahnede kukla sayesinde gerçekleştirilebilmektedir.

"Genel olarak kuklaları konumlandırmak ve hareket ettirmek için, her kuklanın konumu, kukla sahnesiyle ilişkisi, hareket hızı, örüntüsü ya da hareket akışı, ağırlık gerginlik ve gevşemesine bağlı olarak farklı yollar geliştirilir" (Tilroe, 1996:6).

Hareket ve jest kadar onların her bir fragmanını oluşturan duruşlar da anlamı üretme açısından önemlidir. Örneğin sadece oturma eyleminin bir anı bile zihinde bir fikir oluşturabilmektedir. "Dik oturan kişiler, çökük oturan kişilere göre yaşama arzusu yüksek, kendine güvenli ve enerjik yapıdadırlar" (Özdemir, 2012: 39). Dik oturma pozisyonunda omurga düşey olarak sırtı dikey bir çizgide olduğu gibi düz tutmaktadır. Dik duruş, kendine güvenli ve rahat bir ruh hali çağrıştırırken, öne doğru eğik duruş hüzünlü ve yıkılmış ya da yenik bir ruh haline işaret etmektedir. Yürürken de bu anlam bağlantısı kurulur. Beden öne 
doğru eğik iken yavaş bir yürüyüş sergilemek bedensel yorgunluğa işaret edebileceği gibi, ruhen yenik ya da üzüntülü bir duruma da işaret edebilir. Dik duruşta ise yürüme eyleminin hangi hızda gerçekleştiğine göre kişinin ya da kuklanın kendine güvenli, rahat ya da aceleci olduğu konusunda bir sonuca varılabilir. Omurga bir çizgi gibi düşünülürse, o çizginin konumlanışının yaratacağı anlam çağrışımları da dikkate alınmalıdır.

"Çizginin hatırlanması gereken önemli bir özelliği onun yönüdür. Yatay bir çizgi sessiz ve dinlendiricidir bunun sebebi büyük ihtimalle bizim yatay beden pozisyonunu dinlenme ya da uyku ile özdeşleştiriyor olmamızdandır. Dik ayakta duran bir bedene benzeyen dikey çizgi daha fazla hareket potansiyeli taşır. Ama diyagonal çizgi çok daha güçlü bir hareket çağrışımı yapar. Hayatın pek çok aktif anında (kayak, koşu, yüzme, buz pateni) beden eğilmiştir, yani biz otomatik olarak hareket çağrışımı yapan diyagonaller görürüz" (Lauer ve Pentak, 2012:134).

Nikki Tilroe (1996: 20) da kuklanın duruşuyla ilgili yazarken çizgilere gönderme yapmış ve ayakta duran bir kuklanın dikey bir çizgi üzerinde olduğunu belirtmiştir. Yatay bir çizgideki kukla ise uyuyor ya da ölü kabul edilmektedir. Yatay çizgi, insan bedeninin dinlenme anındaki duruşuna benzerliğinden durağanlık ifade eder. Yine Tilroe (1996) denge ve karşıt denge konularında diyagonal çizgilere atıfta bulunarak diyagonal bir çizgide duruyormuş gibi görünen kuklanın dengesinin bozuk olduğu veya düşecekmiş hissi yarattığını belirtmiştir.

Hareket eden figürler, renk, tasarım, jest, hareket, müzik, sahneleme ve metni kapsayan pek çok göstergebilimsel ifadeye olanak tanımaktadır. Figür, insan aktörle ve zaman zaman seyirciyle etkileşime girdiğinden, "metin açısından figürler dialogic (çiftsesli) hatta polygogic (çok sesli) olmaktadır" (Wanrooy, 1995: 9). Burada kastedilen çok sesli olma durumu, ikiden çok oyun kişisinin konuşması olarak yorumlanabileceği gibi burada ifade edilen; anlamsal olarak tüm unsurların eşzamanlı biçimde izleyiciye, görsel yolla konuşuyor yani mesaj aktarıyor oluşudur. Seyirciye oyunun anlatmak istediğini aktarmak çok bileşenli bir yoldur. Disiplinlerarası gösterilerde yazılı metinle birlikte kuklanın ya da nesnenin görüntüsü ve hareketi, fondaki müzik ya da efekt aynı anda başka ifadeler taşıyabilmektedir. Bunlar, anlatılmak isteneni iletirken birer araç olarak birbirini tamamlayacak şekilde kullanıldıkları gibi, birbirlerine ya da anlatının kendisine kontrast oluşturacak şekilde de düzenlenebilirler. Tempolu bir müzikte ağır çekim hareket kullanılması böyle bir kontrasta örnek olabilir.

Sahne üzerinde oran fark1, büyüklük direkt olarak vurgu alarak dikkati çeken bir uyarıcıdır. Uyarıcının büyüklüğü kadar, renk, ses gibi diğer niteliklerinin şiddeti de dikkati etkilemektedir. Renklerin parlaklığı, sesin yüksekliği, kokunun kuvveti dikkati odaklamaktadır. Renkli uyarıcılar renksiz uyarıcılardan daha etkilidir ve renkler arasında da saf renkler karışık renklerden daha çok dikkat çekmektedir (Cüceloğlu, 1997: 122). Büyüklük ve renkle ortaya konan farklar sahnede örneğin karşılıklı duran iki karakterin birbirine göre önemini ve aralarındaki hiyerarşiyi ortaya koymaktadır. Özellikle kukla tiyatrosunda, günlük hayattaki gerçekliğin ötesinde uygulamalar yapılabileceği için; iki karakter arasında boyut ve yükseklik farkı rahatlıkla ortaya konarak aralarındaki hiyerarşi belirlenebilir. Bu noktada yükseklik büyüklükle ilintili olarak kullanılır, zira sahnede bir nesne-beden-karakterin yukarı yükseltilerek büyütülmesi ona anıtsal bir nitelik verecektir. Kukla ve oynatıcısının etkileşime girdiği durumlarda bu boyut farkı, ister kuklanın ister oynatıcısının lehine olsun yine de izleyicide bağlantı kuracağı bir hiyerarşiye gönderme yapmaktadır.

\subsubsection{Sahnede Kuklacı ve Kukla Etkileşimi}

Kuklanın dramatik rolünü yerine getirmesini sağlayan, onu hareket ettiren, yegâne güç, nefes ve ruh kuklacı/oynatıcıdan gelmektedir. Çağdaş kukla tiyatrosunda oynatıcı ya da kuklacı sahne üzerinde görünür olma endişesini taşımamaktadır, aksine çoğunlukla kuklanın yanında aktif bir oyun kişisi olarak yer almaktadır. Bu varyete tipi gösterilerden, sokak gösterilerine ve uzun dramatik oyunlara kadar böyledir. Dans ve hareket tiyatrosu, opera gibi diğer sahne 
sanatlarında da kukla kullanıldığında, onu hareket ettiren kuklacı/oyuncu/dansçının oyunun bir parçası olması söz konusudur.

Oyuncu ve kukla birbirinin rol arkadaşı olduğunda, birbirlerinin eşiti olurlar. Ne kuklacı kuklanın yalnız hareket ettirenidir, ne de kukla oyuncunun yardımcı aksesuarıdır. Esasen oyuncu ve kuklanın sahne sanatlarındaki işlev ve değeri birbirinden çok farklı değildir; zira ikisi de sahnede bir oyun kişisini canlandırmaktadır. Kukla ve insan oyuncunun sahne sanatları açısından işlevlerinin benzerliği, oyunculuk alanındaki kuramcıların da dikkatini çekmiştir. Edward Gordon Craig (1957: 81-85) oyuncu ile kukla arasında bir analoji kurarak bunu übermarionette ile açıklamakta, yani üstün kukla olarak tanımlamaktadır. Kuklacı nasıl kuklaya yön veriyor onun hareketlerine karar veriyorsa yönetmen de oyuncuyu öyle yönlendirmektedir. Dolayısıyla oyuncu elbette kendi değeri ve sahne zekası saklı olarak yönetmenin hayalini sahneye taşımaktadır. Craig, karakterden ziyade hareketli heykelin savunuculuğunu yaparken; Étienne Decroux için oyuncu hem heykel hem de heykeltıraş olarak var olmaktadır. Dolayısıyla insan orada olsa bile unutularak yalnızca figür görülmektedir. Bu durumda figür neredeyse soyut olarak algilanmaktadır (Pezin, 2003: 140, Akt. Heggen ve Marc, 2017: 307). Bu da oyuncunun kendisinden ziyade canlandırdığı oyun kişisinin, sahnenin gerçekliğinde, gündelik yaşam gerçekliğinden farklı bir çeşit illüzyon olarak algılanmasına sebep olmaktadır. Kukla tiyatrosu açısından bu hem kukla hem de kuklacının kendisi için geçerli olabilir. Kukla, Craig'in bahsettiği hareketli heykeldir ve sözsüz oyunlarda çoğunlukla Decroux'nun altını çizdiği gibi temsil ettiği şeye dönüşerek çoğu zaman anlatının nesnesi olmaktadır. Oynatıc1/kuklacı da kendisi oyun kişisi olduğu durumlarda, kuklayı hareket ettiren kişi olma durumundan bir şey kaybetmez; ancak bir yandan o anda kuklacı değil yalnızca oyuncudur. Kuklayı oynattığı ve kendini nötrlediği anlarda ise sahnede tamamen görünmez olmaktadır. Seyirci onun orada olduğunu bilse de görmezden gelir ve yalnızca kuklaya odaklanır. Kuklacının kendini nötralize etmedeki ustalığı ile yakından ilişkili olan bu durum; kuklacıyı bir yandan oyun kişisi olarak heykel, bir yandan da kuklanın hareketini meydana getiren heykeltıraş kılmaktadır.

Konvansiyonel kukla tiyatrosunda alışılmamış olan şey, kukla ve kuklacı arasında seyircinin gözü önünde kurulan göz kontağıdır. Kuklacının özellikle Avrupa geleneğinde sahne arkasında gizlenme alışkanlığı olduğu düşünülürse, kukla ve kuklacı sahne üzerinde yan yana bile gelmemektedir. Ancak çağdaş kukla tiyatrosu, kuklacıyı sahne üzerine çıkarmakla kalmayıp; onu kimi zaman kendi kimliği olan kuklacı olarak kukla ile yüzleştirmekte kimi zaman da başka bir oyun kişisi olarak kuklayla karşı karşıya getirmektedir. Bu durumlar başlı başına oyunun konusunu belirleyebilmektedir. Yalnızca kukla ve kuklacının ikilemini yansıtan oyunlar söz konusudur. Bu noktada kukla türüne kendi adını verdiği tiyatronun amacı olmaktan çıkarak, kendi yapısını sorgulamanın aracı olur. Cansız bir nesne olduğunu ve onu canlandıran oynatıcıyı keşfeder; bu kukla ve oynatıcısı arasında komik ya da dramatik yeni bir diyalog gelişmesine sebep olur. Diğer yandan kukla, sahne üzerinde insan oyuncuların yanındaki karakterlerden biri de olabilir. Bu durumda kukla, Art Stage SAN'ın Dallae'nin Öyküsü adlı oyununda olduğu gibi büyük resmi tamamlayan sembolik değeri olan bir araç konumundadır.

Kuklanın sahnede kendi başına bir irade göstererek kuklacıya karşı gelmesi bir çatışma yaratmaktadır. Bu da o ana kadar oynatıcı ve kukla arasındaki önden kabul edilmiş güç ilişkisini tersine çevirmektedir. Hali hazırda oynatıcının canlandırıcı güç olduğunun bilinmesi, yeni oluşan durumun inandırıcılığını etkilememesi oynatım becerisi ile doğrudan ilintilidir. Oynatım becerisindeki ustalık sonucunda oluşan yeni durum kuklanın üstünlüğünü sergileyen yeni ve konvansiyonele kıyasla alışılmadık bir karşıtlığı beraberinde getirmektedir.

Çağdaş sahneleme örneklerinde, kukla, tek başına oyunun tek aktörü olmayıp aktörlerden biridir. Kuklacı hem kuklayı oynatma görevini üstlenip hem de oyundaki karakterlerden biri olabilir ya da kuklacı yalnızca kuklayı oynatma işlevini yerine getirirken, 
onun dișında sahnede kuklaya eşlik eden oyuncular da söz konusu olabilmektedir. Dallae'nin Öyküsü adlı oyun, Kore Savaşı zamanında bir ailenin öyküsünü anlatmaktadır. Bir kukla olarak canlandırılan Dallae, doğumundan itibaren ailesiyle geçirdiği mutlu anlar içinde görülmekte; savaşın başlamasıyla mutlu anlar yerini zorlu zamanlara bırakmaktadır. Diğger tüm yetişkinler insan oyuncular tarafından canlandırılmaktadır. Buradaki analoji, kuklaların kendi iradesi ile hareket edememesi gibi, çocukların kendi hayatları üzerinde kontrollerinin olmamasıdır. Dallae yetişkinlerin dünyasında onların sebep olduğu bir savaşın getirdikleri karşısında çaresizdir. Kukla ve kuklacısı arasındaki boyut farkı da kuklayı yönlendirenin kuklacı olması da ebeveyn ve çocuk arasındaki ilişki dinamiğini anımsatması sebebiyle bu görüntünün kabul görmesini kolaylaştırmaktadır.

Kimi oyunlarda kukla, gerçek insan olan oynatıcısının bedeni ile kendi bedeni arasındaki farkları keşfetmektedir. Böyle durumlarda kukla özne iken, nesne olduğu farkındalığını yaşar ve seyirciye canlı kuklacı ve cansız kukla karşıtlığını göstermektedir. Buna ek olarak, kuklanın kendini diğer herkesten farklı hissettiği vurgusu yapılabilir.

Yukarıda da ifade edildiği gibi kukla, çağdaş oyunlarda sahnede hem bir nesne hem de özne olabilmektedir. Bu ikili kullanım, oyunun anlam katmanlarının çoğalmasını ve izleyici için hazzı arttırarak oyunun zenginleşmesini sağlamaktadır. Kuklanın eşzamanlı olarak hem nesne hem de özne olarak algılanması, onun sahne üzerindeki gücünü arttırır, aynı zamanda seyircinin de daimî olarak sahnede olan biteni ve değişen ilişkiyi düşünmesine yol açar. Hem kuklacının hem de kuklanın da başlı başına ifade aracı haline geldiği, mesajın öne çıktığı bu sebeple de oyunu meydana getiren unsurların her birinin birer imge olduğu durumlar da söz konusudur. Büyük olan şeylerin genellikle daha yüce, güçlü ve korkutucu olana işaret etmesi sebebiyle küçük kuklanın karșısındaki dev el tanrısal bir gücü çağrıștırmaktadır. Kuklanın iplerinin kuklacının elinde olması gibi, insan hayatının da yaratıcı gücün elinde olduğunu sembolize etmektedir.

Çağdaş kukla oyunlarında ve diğer disiplinlerarası çalışmalarda kukla ve oynatıcısının ilişkisi çok boyutlu bir hale gelmektedir. Kukla ve oynatıcısının aynı anda sahnede olması, aralarındaki ilişkinin dinamiği, değişen güç dengesi, kuklayı da oynatıcısını da onlardan beklenen rollerden sıyırmaktadır. Böyle değerlendirildiğinde, oynatıcı sadece kuklaya hareket veren olmaktan öte olur; kukla da pasif bir nesne, bir sahne aksesuarından ya da bir yardımcı oyuncudan fazlasıdır. İlişsinin boyut kazanmasında oyun kişilerinin ele alınış biçiminin de etkisi vardır. Karakter yaratmak oyunculuk kuramlarında da tartışılagelmiştir. Ommaney’nin tiyatroda oyunu analiz etmek için sorduğu soruların karakterlerle ilgili olanları, bir kukla oyununu sahnelerken kuklacının da kendisine sormasının faydalı olacağı sorulardır.

"1. Karakterler gerçek hayata uygun mu? 2. Oyun boyunca devam eden aksiyonda tutarlılar mı? 3. Oyunun sosyal ve coğrafi arka planı ile uyumlular mı? 4. Sempati, ilgi, tiksinti, hayranlık ya da nefret gibi duyguları seyircide kesin olarak uyandırabiliyorlar mı? 5. Hareketleri gerekçeleri ile uyumlu mu? 6. Oyunun dönüm noktası ve sonuç bölümündeki durumlar karakterin kendi doğasında olan şeylerin bir sonucu mu?" (Ommaney, 1950: 114).

Yukarıdaki sorular kukla oyununun dramaturgik bütünlüğü için son derece önemlidir. Kukla karakterinin tasarımı ya da hareket düzeniyle, ilgi çekici olması seyirciyi oyuna ve sahnede olup biteceklere ilk bağlayan şeydir. Kukla karakterinin gerçek hayatı anımsatması, tasarımından ziyade durumlara tepkileri ve hareketlerinin gerçekçiliğiyle bağlantılıdır. Zira kukla tasarım olarak sokakta görülebilecek herhangi bir nesne ya da canlıya hiç benzemeyen bir biçimde olabilir. Yine de kuklanın canlı olduğu, insanın en temelde okuyabileceği nefes alışverişi ve hareket etmesi ile anlaşılmaktadır. Kuklanın hareketsiz kalması onun ölü olduğuna işaret eden güçlü bir göstergedir. Kukla karakteri ile duygu bağı kurulması, seyircinin onun gerçek olduğuna inanması ve öykü boyunca onu takip etmesi için gereklidir. Karakterin içinde 
bulunduğu duruma göre jest ve hareketleri ikna edici, anlaşı1ır biçimde açık ve her biri mutlaka mantıklı biçimde gerekçelendirilmiş olmalıdır. Özellikle kukla tiyatrosunda, oyunun kurgusu, durum ve kukla karakteriyle hiçbir şekilde ilişkilendirilemeyecek hareketler, oyunun ve karakterin anlaşılmasını olumsuz yönde etkilemektedir. Tüm aksiyon karakterleri ve onların içinde bulunduğu durumu tasvir etmeye yardımcı olacak biçimde ve en ekonomik hareket seçkisi ile planlanmalıdır. Son olarak da kukla oyununda aksiyon anlaşılır, gerçekçi, uygun süreli ve tüm seyirci tarafından görülecek kadar abartılı olmalıdır. Abartılı olma durumu, kukla tiyatrosunda özellikle önem arz etmektedir. Kuklayı eşsiz kılan, tasarımda abartılarak öne çıkarılan kişilik özelliğgi, duygu ya da görsel öğe olsun, gerçek hayattakinden daha fazlasıduruma göre daha azı- olup bir yandan aynı etkileme gücüne sahip olmasıdır. Bir kukla sadece dev bir el olabilir, naylon torbadan yapılan amorf biçimler ya da günlük hayatta görülen biçimler de olabilir; yine de anlam oluşturma ve duygulanım yaratma konusunda son derece etkin olabilmektedir. Öyle ki, kimi zaman gerçek oyuncunun sahnede yarattığ etkiden çok daha fazlasını yaratabilmektedir. Bununla birlikte oynatıcısı ile olan ilişkisinde de yukarıdaki soruların cevaplanması önem arz etmektedir. Kukla ve oynatıcısının sahne üzerindeki varlığ ve ilişkisi gerekçelendirilmiş ve oyunun kendi gerçekliği içinde tutarlı ve inandırıcı olmalıdır. Seyirciyi kukla ve oynatıcısı arasındaki dinamik üzerine düşündürmeyi amaçlasa dahi anlam çerçevesini tutarlı olarak kurgulamak anlaşılırlık için gereklidir.

Bugün çağdaş oyun kurguları, oynatıcıyı kuklanın hareket ettiricisi olmaktan öte oyunun bir parçası kılan, oyunu meydana getiren tüm unsurlara eşit şekilde rol verecek biçimde oluşturulmaktadır. Kukla ve oynatıcı sahne dışındaki bu rolleri ile ya da canlandırdıkları roller çerçevesinde oyun dramaturgisine katkıda bulunmaktadırlar. Oynatıcı, salt kuklacı, ilahi güç, ebeveyn, otorite, patron gibi rollerle kuklaya hareket veren kişi olmasından ötürü güçlü bir konumda kuklanın karşısına çıkabildiği gibi kuklanın egemenliği altına da girebilmektedir. Kimi oyunlarda farklı kuklalarla farklı düzeylerde ilişki kurabilmekte; kukla ve oynatıcı arasında değişen dinamikler ve bu dinamiğin anlarını oluşturan imge ve görüntüler sahnede anlam çeşitliliği yaratmaktadır. Bu çeşitlilik de özellikle disiplinlerarası çalışmalar içinde değerlendirildiğinde seyirci için ilgi çekici ve düşündürücü sonuçlara sebep olmaktadır. Sahne dışında kurulan ilişki ve algılama biçimi konvansiyonel kukla oyunları için oyunun dişında kalmaktadır. Çağdaş oyunlarda ise kuklacılar bu dinamiği de konu olarak sahneye taşımaktadırlar.

\section{3.İçerik}

Kısa skeçlerden oluşan bir hikaye anlatmaktan ziyade oynatım hüneri sergilenen oyunlar haricinde diğer gösteriler kültüre özgü konular bile olsa onların evrensele hitap eden yanlarını öne çıkararak kendilerini anlaşılır kılmaktadır. Hareket tiyatrosu yapan ancak çağdaş tiyatro anlayışı çerçevesinde, nesne ve kukla da kullanarak tiyatral dilin olasılıklarına da olanak tanıyan Théâtre du Mouvement oyunlar için kendilerine kaynaklık eden referansların "sıklıkla kültürlerarası güçlü arketipler (doğum, ölüm, aile, yürüme, vb.)" (http://theatredumouvement.fr/en/philosophy/) olduğunu belirtmişlerdir. "İmgenin önemli bir rol sahibi olduğu ve tüm görsel sanatlar üzerine olan araştırmaların dışavurum, soyutlama, gerçekçilik ve hayal gücü ile dokunmuş olduğu bir dünyada" oyunların seyirci tarafindan okunması ve iletinin istenilen biçimde ulaşması son derece kolaylaşmaktadır. Öte yandan bir şeyi anlamak için ne kadar çok duyu kullanılır ise anlam o kadar üç boyutlu hale gelmektedir. Kukla tiyatroları da ellerinin altındaki anlam ileten araçları çoğalttıkça, oyundan farklı katmanlarda anlam okuması mümkün olmaktadır. Bu bağlamda Lecoq'un öğrencilerle yaptığ sözcük, renk, müzik ve şiiri temel alan alıştırmalar çağdaş kukla oyunlarında tek tek ya da birlikte oyun oluşturma aşamasında kullanılan nosyonlar olarak değerlendirilebilirler. Alman Theater Waidspeicher'in Romeo ve Juliet'te sözcükleri tamamıla hareket diline dönüştürmüştür. Karin Schäfer Figuren Theater'ın Pictures At An Exhibition oyununda müzik 
görsel estetiğin üretimine olanak vermiştir. Cie Acide Mélancolique'in Red Shoes oyununda şiirsel metin ilham kaynağı olmuş ve hareket temelli oyunun zeminini oluşturmaktadır. Üç oyun da sahnelenmeleri sırasında, hareket, nesne, kukla, dans ve müzikten faydalanmıştır.

Oyunların konusu ne olursa olsun kumpanyaların başvurduğu beden dili evrensel ifadeleri içermektedir. Ölüm, doğum, savaş gibi olaylar karşısında insanlar kültür farklılıklarına rağmen aynı duyguları deneyimlemektedirler. Oyun kişilerinin tepkileri de insanlık için ortak olan evrensel duyguları görselleştirecek biçimde hareket diline çevrilmektedir. Yani sahnelemede tasarım ve hareket anlamında çoğunluğun okuyabileceği biçimler tercih edilmektedir. Dikkati çeken, kumpanyaların tema-tasarım-hareket uyumunu ensamble çalışarak çoğunlukla da farklı disiplinlerle işbirliği içine girerek yakalamalarıdır. Tasarım (malzeme), hareket, tema uygunluğu sağlandığında; kimi anlarda bu uyumun bozulmasıyla da sahnede ilginçlik öğesi ortaya konarak seyircinin alacağı estetik haz arttırılmaktadır. $\mathrm{Bu}$ belirleyenlerle kukla tiyatrosu, tüm plastik ve sahne sanatlarını içine alan bir bütün olarak sahnede anlatılmak istenen öykü ve verilmek istenen mesajın görüntü ve hareketle aktarılmasına olanak tanımaktadır. Tiyatro için hareketli resim yakıştırmasının doğru olduğu kabul edilirse, kukla tiyatrosu kukla yapım bağlamında zanaatçılı̆̆ da içine alacak şekilde bu yakıştırmayı sahiplenebilir. Kukla yapımı sahne sanatlarının bir türüne oyun kişisi sağlama anlamında hem sanat hem de zanaattır. Kuklacı aynı zamanda yapımcı ve oynatıcı ise pek çok rolü aynı anda taşıyan bu anlamda oyunun da omurgasını kurgulayan kişi olmaktadır.

Çağdaş kuklacılık anlam arayışında imge ve görsel dilden fazlasıyla faydalanırken; geleneksel kukla teknikleri hem yapım hem de oynatım açısından çağdaş uygulamalara kaynaklık etmektedir. Bu bağlamda ipli kukla, gölge kuklası, el kuklası ve Japon bunraku gibi teknikler yeni uygulamalara da ilham vermektedir. Teknik olarak ne seçilirse seçilsin mesajın evrensel olmasına çalışılır. Lecoq'un dediği gibi "daha basit ama daha güçlü teatral [...]biçimlerin kökleri herkesin anlayabildiği hayatın içinde bulunuyor" (Lecoq, 2015: 185). Dolayısıyla insanların binyıllar boyunca kültürler ötesinde kolektif hafızasına yerleşmiş olan, doğanın içinde ve birlikte yaşamanın getirdiği hareket ve duygular yaygın olarak okunabilmektedir. İletişim araçları ve internet de kültürel kodlar ve sembollerin yaygın şekilde tanınmasını sağlamaktadır. Sevgi, nefret, intikam, korku, neşe, üzüntü, öfke gibi duygularla savaş, göç, ölüm, anne-çocuk ilişkisi, ast-üst ilişkisi gibi olay ve olgular; kültürel ayrımların ötesinde tüm insanların tecrübe ettiği ya da şahit olmalarından ötürü sahnede de anlamlandırabilecekleri görüntülerdir. Hayata dair bu durumlar, konvansiyonel kukla tiyatrosunda yalnızca kuklalar arasında gerçekleşirken, 20. yüzyıldan itibaren kuklacı ve kukla arasında vuku bulmaya başlamıştır. Çağdaş oyunlarda sahne üzerindeki estetik dinamik kuklacının ya da oynatıcının kukla ile olan ilişkisinden de beslenir olmuştur.

\section{SONUÇ}

Kukla tiyatrosunda, malzemenin kaynaklık ettiği, sahne metnine dayanan, farklı disiplinlerden sanatçıların birlikte çalışması sonucu sahnelenen oyunlar giderek çoğalmaktadır. İlk tohumlarını belki de Wagner'in gesamtkunstwerk (toplu sanat yapıtı) ile attığı, avangard tiyatro çalışmalarında denenmiş; bugün toplu yaratım da denen türetim tiyatrosu (devised theater) ile çağdaş kukla kumpanyalarının çalışma biçimi son derece benzerdir. Farklı uzmanlık alanlarından profesyoneller, prova odasında buluşur ve çıkış noktaları ne olursa olsun yazılı bir metni, hareket düzenini ya da sahne metnini birlikte oluştururlar. Provalar sırasında denemeler ve doğaçlama çalışmalar sahnede işlevsel olanı ve olmayanı ortaya koyar böylelikle de oyun ortaya çıkar.

Disiplinlerarası çalışmalar yapan kumpanyalar için kumpanyanın kendisini ya da gösteriyi nasıl tanımladığı işin tanıtım ayağında önemli olduğu kadar, kuramcılar için de oyunu konumlandırma bakımından düşündürücüdür. Dolayısıyla hem avantajlı hem de dezavantajlı 
bir durum oluşturmaktadır. Disiplinlerarası çalışmanın belki de en büyük avantajı, farklı disiplinlerin katkısıyla hem anlam hem de ifade açısından gösterinin zenginleşmesi dolayısıyla da ilginçleşmesidir. Yine de sahne sanatlarının keskin ayrılıklarının giderek ortadan kalktığ 1 ve işbirliklerinin çoğaldığı görülmektedir. Bir yandan uluslararası festivallerin bu disiplinlerarası gösterimlere alan açması, benzer çalışma yapan sanatçıları cesaretlendirmektedir. Letni Letna Sirk Tiyatrosu Festivali gibi festivaller, disiplinlerarası gösterilere ve kuklalı oyunlara programlarında yer vermektedir.

Kuklanın ana etmen ya da baş oyun kişisi olmadığı çağdaş gösteriler, dünyadaki diğer kukla festivallerinde de giderek daha çok kendilerine yer bulmaktadırlar. Kukla bir anlatım aracı olarak, gösteriyi izleyen seyirciye farklı perspektiften bakma olanağı sunmakta, anlatılmak isteneni boyutlandırmakta ve çok katmanlı hale getirmektedir. Sirk tiyatrosu, dans tiyatrosu, opera gibi türler çağdaş gösterimlerinde kuklaya yer verirler; ancak gösterilerin tamamı kukla tiyatrosu dinamikleri üzerine kurulmamıştır. Kuklalar ya da kukla gibi işlev gören her birim aslında anlamı destekleyici bir işleve sahip olabildiği için bu oyunların bir parçası olmuştur.

Çağdaş oyun kurguları, oynatıcıyı kuklanın hareket ettiricisi olmaktan öte oyunun bir parçası kılarak; oyunu meydana getiren tüm unsurlara eşit şekilde rol verecek biçimde oluşturulmaktadır. Oynatıcının sahnede görünür olmasıyla kuklayı salt canlandıran kişi olmanın ötesinde; bir oyun kişisi olarak kuklanın rol arkadaşı olması da söz konusudur. Aynı zamanda oynatıc1/kuklacı oyun boyunca rol değiştirebilir. Aynı zamanda, oyun içinde hem oynatıcı hem rol olarak kuklacı hem de başka bir oyun kişisi olabilir. Oynatıcı olarak sahnede edilgen ve nötr konumda iken oyun kişisi olarak etken ve aktiftir. Bu ikilik oyuna çok boyutlu bir yaklaşım getirmektedir. Konvansiyonelde kuklacının hep edilgen olması söz konusuyken, çağdaş kukla tiyatrosunda etken bir role bürünmesi kuralların dışında yenilikçi ve şaşırtıcı bir etki yaratmakla kalmayıp kukla ve kuklacı arasında sahne üzerinde gözlenen bir diyalog oluşmaktadır. Bu diyalog ikisinin de birer oyun kişisini canlandırması ile kurulabildiği gibi, kuklanın kukla olduğunun bilincinde, kuklacının da kuklacı olduğunun bilincinde olarak da kurulabilir. Compagnie 1'Alinéa'nın Short Stories Without Words'de olduğu gibi ikisi de birbirinin hareketine tepki vermektedir. Kukla kendini harekete geçireni keşfetmektedir. Kuklacı ve kukla arasında bu şekilde gelişen diyalog söze ya da harekete bağlı olabilir. 21. yüzyılın kukla kumpanyaları disiplinlerarası çalışmalara açıktır. Farklı disiplinler de kuklaları projelere daha çok dahil etmektedir. Konvansiyonel kumpanyalar kendi içlerinde oyunların oluşturup icra ederken, çağdaş ekipler farklı sanat disiplinleri kadar teknik uzmanlık alanlarından kişilerle de ortak çalışmalar yürütmektedirler. Ayrıca konvansiyonel kukla oyunlarında tek teknik kullanılırken, çağdaş oyunlarda farklı kukla teknikleri bir arada kullanılabilmektedir. Özetle görsel dilin ağırlıklı olduğu bir anlatı için temel tasarım kurallarından, ortak imgelere ve hareketlere her şey iletilmek istenenin seyirciye ulaşması için araçtır. Kukla, oynatıcı için aynı anda nesne, özne; araç ve amaç olmaktadır. Bu bağlamda, müzik, metin, hareket, dans, oyuncu, kukla, sahne/mekan, projeksiyon, animasyon, dekor, maske, makyaj vb. tüm unsurlar gerektikleri ve oyuna katkı sağladıkları kadar disiplinlerarası sahnelemelerde biri diğerini gölgelemeyecek şekilde kullanılmaktadırlar. Kendi kullanım alanlarının sınırlarında kullanılmalarının ötesinde, diğer disiplinlerle etkileşime girerek seyirciyi beklenmeyen ile şaşırtmaktadırlar. Özellikle uluslararası gösterimleri bulunan kumpanyalar bugün giderek daha fazla, kültürel farklılıkların ötesindeki insana özgü olan ortak duygu ve olgulara yönelmektedir. Bunun için mim, hareket tiyatrosu, mask tiyatrosu ve animasyon disiplinlerinin imge ile ileti için kullandıkları soyutlama ve indirgeme teknikleri faydalı olmaktadir.

Kuklanın başlı başına oyunun tek aktörü olduğu geleneksel yapıdan, gösteriyi oluşturan eşit önemdeki öğelerden biri konumuna gelmesi; bu tiyatro türündeki en belirgin değişikliktir. 
Aktörü olduğu oyunda, oyunun başat öğesi olsun ya da olmasın aynı zamanda simge olarak da işlev görmesi söz konusudur. Dolayısıyla kukla, içinde yer aldığı bütünde, çok katmanlı bir işleve sahip olmaktadır.

Kukla:

-Sadece bir kuklayı temsilen sahnede bulunabilir.

-Karakterlerden biri olabilir.

-Kukla insan oyuncunun sahne üzerinde gerçekleştirmesinin mümkün olmadığı aksiyonları gerçekleştirebilecek bir imgesel kaynak olarak kullanılabilir.

-Kukla herhangi bir fikri, duyguyu veya durumu temsil eden bir semboldür.

Kukla tüm bu özellikleri ile hareketli bir bebekten çok daha fazlasıdır. Konvansiyonel olandan uzaklaşma ve öze dönme çabası ile bugünün kukla tiyatrosu ifadede daha rafine ve etkili olma arayışındadır. Avangard akımlar 20. yüzyıl başında, sanatlar arasındaki sınırların tam anlamıyla çözülmesine ve bu bağlamda yapılan denemelerle farklı sentezlerin söz konusu olmasına olanak sağlamıştır. Denemeler, yeni ve çağdaş olanın kapılarını açmıştır; ki bugün kukla tiyatrosu için yeni bir avangardın söz konusu olduğu söylenebilir. Bugün yalnızca sanat dalları arasındaki sınırların çözülmesi değil, ülke ve kültürler arasındaki sınırların da çözülmesi söz konusudur. İletişim teknolojileri bilginin hızlı ve geniş yayılımasını sağlamakta, aynı zamanda sahne sanatlarına da sahneleme açısından ilginçlik unsurunu arttıracak farklı olanaklar sunmaktadır. Projeksiyon, internet sayesinde kamera ile sahnede canlı gösterimler, mapping, hareket okuyucu sensörler gibi yenilikler yönetmenler, oyuncular ve tasarımcıların disiplinlerarası ve çağdaş uygulamalarda yaratıcılıklarının sınırlarını zorlayacak ürünler ortaya koymasını sağlamaktadır. Gelişen teknoloji de hem kuklanın hem de ifade biçimlerinin zenginleşmesini sağlamaktadır.

Uluslararası kukla festivalleri de çağdaş kukla ve sahne sanatları alanında çalışanları bir araya getirerek, kültürden beslense de kültür sınırlarını aşan gösterilere hem zemin hazırlamakta hem de giderek daha fazla yer vermektedir. Görsel dil ve imgelerin olanak tanıdığı sınırlar ötesi ifade biçimi; tasarım unsurlarının doğa ile bağlantılı evrensel niteliklerinden beslenmektedir. Hareket ve jestlerde de fizyolojik kökenli doğal tepkiler herkesin anlayabileceği beden dili okumalarına izin vermektedir. Tüm bunlarla birlikte sahne arkasında gizlenmeyi birakan kuklacı/oynatıcı kukla ile birlikte oyunun anlam katmanlarını zenginleştirecek yeni bir etkileşim olanağı bulmaktadır. 


\section{KAYNAKÇA}

AMBROSE, Gavin, HARRIS, Paul (2013). Grafik Tasarımda İmge. (Çev. Mustafa Kemal İz) İstanbul: Literatür Kitabevi.

BARTHES, Roland (2002). S/Z. New York: Blackwell.

CRAIG, Edward Gordon (1957). On The Art of The Theater . London: Heinemann.

CÜCELOĞLU, Doğan (1997). Insan ve Davranışı. İstanbul: Remzi Kitabevi.

FISKE, John (1996). İletişim Çalışmalarına Giriş. Ankara: Bilim ve Sanat Yayınları/Ark.

GÜNAY, Doğan (2012). "Görsel Göstergebilim ve İmgenin Anlamlandırılması”, Görsel Göstergebilim (Ed. V. Doğan Günay ve Alev F. Parsa), İstanbul: Es Yayınları, ss. 1155.

HAYLER, Matt (2016). "Another Way of Looking: Reflexive Technologies and How They Change the World", Theatre, Performance and Cognition (Ed. Rhonda Blair ve Amy Cook), London: Bloomsbury Methuen Drama Publishing, ss. 159-173.

HEGGEN, Claire, MARC, Yves (2017). Théâtre Du Mouvement. Montpellier: Deuxième époque .

JURKOWSKI, Henryk (2000). Métamorphosis. Charleville-Mézières: Institut International De La Marionnette.

KEPES, Gyorgy (1969). Language of Vision. Chicago: Paul Theobald and Company .

LAKOFF, George, NUNEZ, Rafael (2000). Where Mathematics Come From: How The Embodied Mind Brings Mathematics Into Being. New York: Basic Books.

LAUER, David A., PENTAK, Stephen (2012). Design Basics, Boston: 127 Wadsworth Cengage Learning.

LECOQ, Jacques (2015). Şiirsel Beden Yaratıcı Tiyatro Eğitimi. Ankara: Nota Bene Yayınları.

MCCORMICK, John, PRATASIC, Bennie (2004). Popular Puppet Theater in Europe 18001914. Cambridge: Cambridge University Press.

MCPHARLAIN, Paul (1969). The Puppet Theater in America. Boston: Plays Inc.

MESCHKE, Michael (1992). In Search of Aesthetics for the Puppet Theater. New Delhi: Sterling.

MEHRABIAN, Albert (1971). Silent Language. Belmont, California: Wadsworth Publishing Company Inc.

OBRAZTSOV, Sergei (1985). My Profession. Moscow: Raduga Publishers.

OMMANNEY, Katherine Anne ve OMMANNEY, Pierce C. (1950). The Stage \& The School. New York: McGraw-Hill Book Company Inc.

ÖZDEMİR, Ali (2012). Beden Dili Etkili Illetişim Etkili Konuşma. Ankara: Altınpost Yayınc1lik.

TILLIS, Steve (1992). Toward an Aesthetics of The Puppet. Westport: Grennwood Press.

TILROE, Nikki (1996). Movement in Puppetry Performance. Bicester,Oxon: DaSilva Puppet Books. 
VOGELS, Frits (1998). "Following Indications of Space and Objects of Movement Theater on Specific Sites”. BLUM, Lambert, HEGGEN, Claire, VOGELS , Frits, TEMPLERAUD, Jacques, HENRY, Philippe, CÉLAIS, Jean-Paul, STEIJN, Robert, LEEKER, Martina. Blue Report 6: Object Theatre Body and Object. Amsterdam: Theater Instituut Nederland

WANROOY, Willem (1995). Figures in Motion. Willem Wanrooy.

WANROOY, Willem (1996a). The Theatrical Inanimate. Unknown: Wanrooy, Willem.

WANROOY, Willem (1996b). Figures in Motion: A Treatise. Willem F. Wanrooy.

La Compagnie l'Alinéa (2017). Le Blog de la Cie l'Alinéa. Retrieved from http://ciealinea.blogspot.com: http://ciealinea.blogspot.com/p/petites-histoires-sansparoles.html [04.07.2017]

Theatre du Mouvement (2017). http://theatredumouvement.fr/en/philosophy/ 